\title{
Amination of oligofunctionalized dinaphthylmethanes: factors affecting the reaction pathway
}

\author{
Vera I. Maslennikova,* Lyudmila V. Shelenkova, Olga S. Serkova, Larisa K. Vasyanina, \\ and Edward E. Nifantiev
}

Department of Chemistry, Moscow Pedagogical State University, 3 Nesvizhski per., 119021 Moscow, Russian Federation

E-mail: him-vim@mail.ru

\begin{abstract}
The reactions of oligofunctionalized 1,1-dinaphthylmethanes with primary amines and ammonia are described. In the reaction of amines with 2,2',7,7'-tetrahydroxy- and 2,2'-dihydroxy-1,1dinaphthylmethanes, the replacement of hydroxy groups by amino groups is accompanied by cleavage of $\mathrm{C}-\mathrm{C}$ bonds and elimination of a methylene unit. The regiodirection of the process is determined by the number and the nature of substituents in the dinaphthylmethane core. The catalytic amination of 2,2',7,7'-tetrakis(trifluoromethanesulfonyloxy)-1,1-dinaphthylmethane is not accompanied by destruction of the dinaphthylmethane core. The reaction selectivity and the product structure depend on the nature of the aminating reagent.
\end{abstract}

Keywords: Dinaphthylmethanes, amination, triflation, microwave irradiation

\section{Introduction}

The broad applicability of aromatic amines has been attracting the attention of chemists for more than one hundred years. The production of dyes, explosives, biologically active compounds, and ligands for metal complex catalysis does not exhaust the list of applications of arylamines. The tendency for constructing complex oligoaminated aromatic systems manifested today ${ }^{1}$ drives the search for new substrates for amination and the development of methods for their modification. In this study, 2,2',7,7'-tetrahydroxy-1,1-dinaphthylmethane containing two pairs of hydroxy groups differing in reactivity is used as the amination substrate. ${ }^{2} \mathrm{We}$ found only one publication on the amination of oligohydroxy-1,1-dinaphthylmethanes. A German patent of $1893^{3}$ describes the reactions of 2,2',7,7'-tetrahydroxy-1,1-dinaphthylmethane (1) and 2,2'-dihydroxy-1,1'dinaphthylmethane (2) with aniline in the presence of aniline hydrochloride. The authors of the patent assumed that the reaction products were 2,2',7,7'-tetraphenylamino-1,1-dinaphthylmethane and 2,2'-diphenylamino-1,1-dinaphthylmethane. 


\section{Results and Discussion}

We carried out the reaction of tetrahydroxy-1,1-dinaphthylmethane 1 with aniline under the conditions indicated in the patent ${ }^{3}$. A mixture of $\mathbf{1}$, aniline, and aniline hydrochloride was heated for $6 \mathrm{~h}$ at $200{ }^{\circ} \mathrm{C}$. Analysis of the isolated products by modern physicochemical methods demonstrated that our results ${ }^{4}$ differ from the data reported in the patent, indicating an unusual course of the reaction that cannot be described within the framework of known naphthol amination reactions. ${ }^{5}$ First, the reaction ended by the formation of two products whose yields after column chromatography were 3 (3) and 38 (4)\% (Scheme 1).

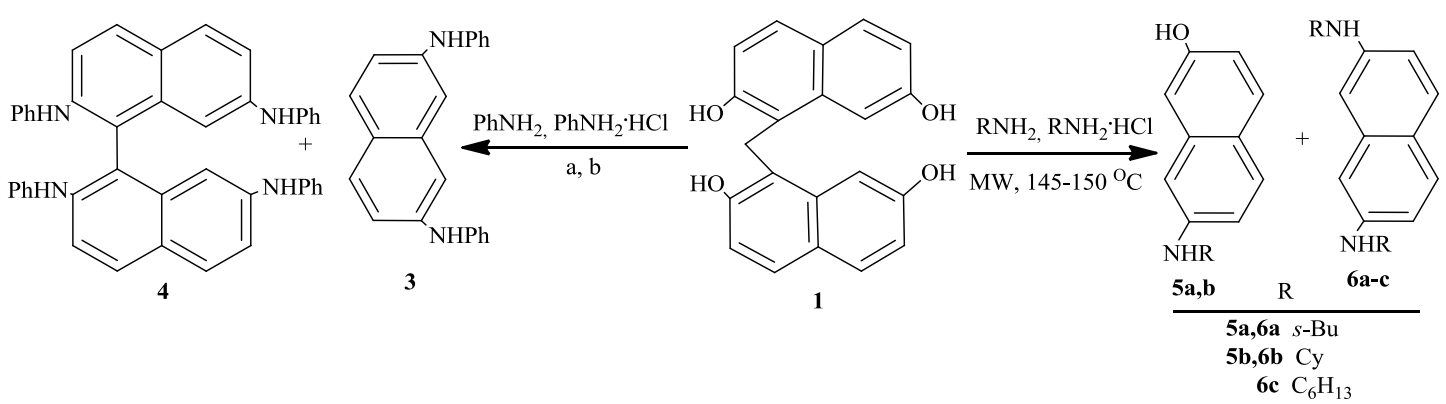

Scheme 1. Reaction of $\mathbf{1}$ with aniline and primary amines. Reaction conditions: $a, 200{ }^{\circ} \mathrm{C} ; b$, Microwave activation (MW), $145-150^{\circ} \mathrm{C}$.

Second, the ${ }^{1} \mathrm{H}$ and ${ }^{13} \mathrm{C}$ NMR spectra of both products did not contain signals for the methylene unit. The ${ }^{1} \mathrm{H}$ NMR spectra contained proton signals for phenyl and naphthyl rings and a signal in the region typical of $\mathrm{NH}$ protons, while the ${ }^{13} \mathrm{C}$ NMR spectra contained signals only for aromatic carbon atoms. Third, according to mass spectrometry, the mass of the major product corresponded to $2,2^{\prime}, 7,7^{\prime}$-tetra(phenylamino)binaphthyl (4) and the mass of the minor product corresponded to 2,7-bis(phenylamino)naphthalene (3).

These facts demonstrated that during the reaction of compound $\mathbf{1}$ with aniline in the presence of aniline hydrochloride, aminolysis is accompanied by cleavage of the bridging $\mathrm{C}-\mathrm{C}$ bonds and elimination of the methylene unit. In order to study this unusual process, here we investigated in detail the reaction of 2,2',7,7'-tetrahydroxy-1,1-dinaphthylmethane (1) with primary amines of different nature and with ammonia.

The amination of 2,2',7,7'-tetrahydroxy-1,1-dinaphthylmethane (1) with primary amines was performed in a microwave reactor at $145-150{ }^{\circ} \mathrm{C}$ in the presence of amine hydrochlorides. The products 3- 6 were isolated by column chromatography.

The reaction of 1 with aniline followed the above-indicated route (Scheme 1). The use of microwave radiation intensified the process, and, hence, the temperature could be reduced to 145 ${ }^{\circ} \mathrm{C}$ and the reaction time was shortened to $2 \mathrm{~h}$, the yields of aminated products 3 and $\mathbf{4}$ being increased to $5 \%$ and $58 \%$, respectively. 
The reactions of $\mathbf{1}$ with aliphatic amines (sec-butylamine, cyclohexylamine, hexylamine) gave, as the major products, mono- and diaminated naphthalenes $\mathbf{5 a}, \mathbf{b}$ and $\mathbf{6 a - c}$ in a ratio depending on the structure of the substituent at the nitrogen atom (Scheme 1).
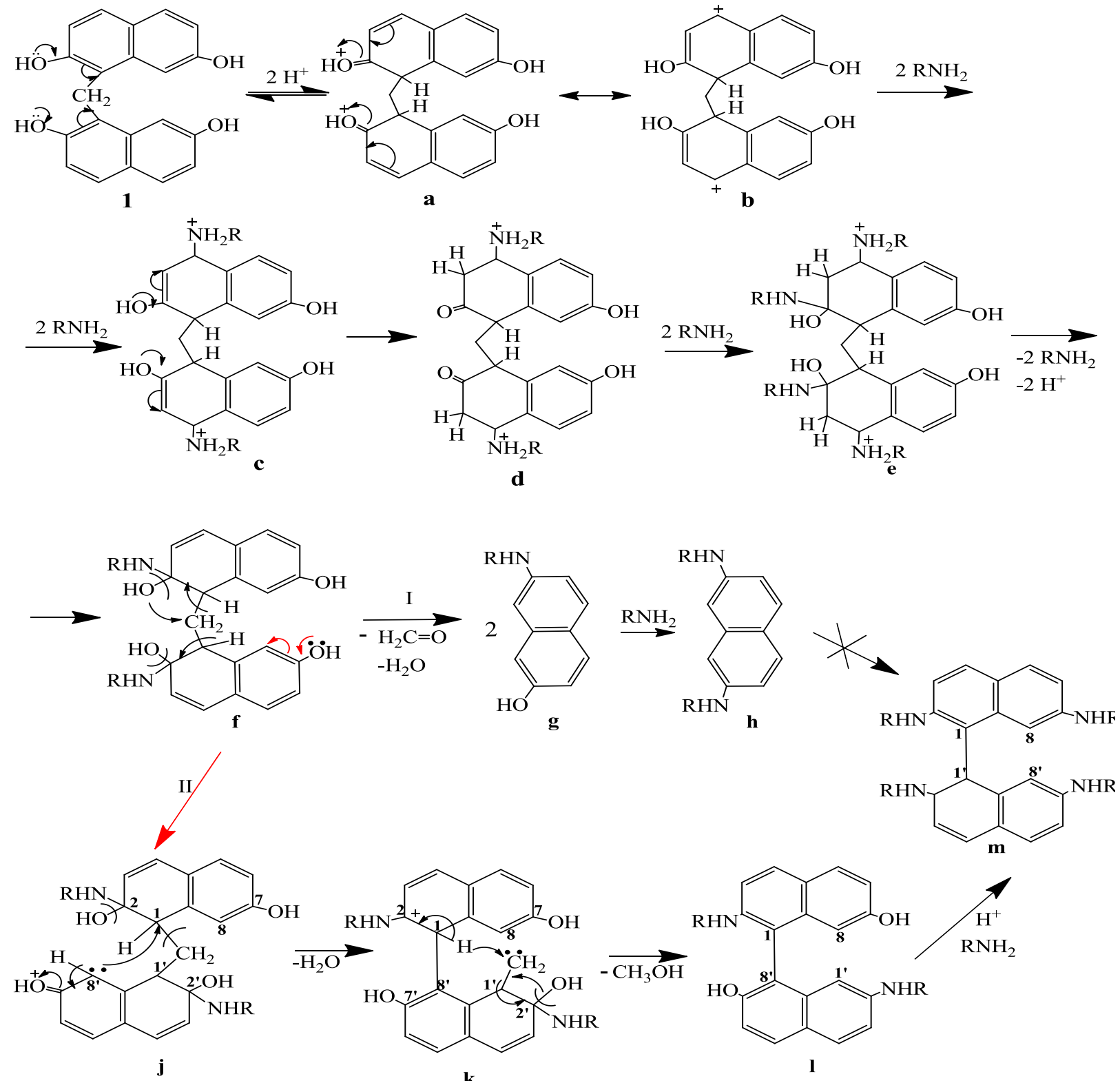

Scheme 2. Proposed rationale for the reactions of $\mathbf{1}$ with primary amines.

The symmetrical structure of diaminonaphthalenes $\mathbf{6}$ is indicated by the presence of three doublets for the naphthalene ring protons with equal integrated intensities in the ${ }^{1} \mathrm{H}$ NMR spectra and by the presence of three singlets for tertiary carbon atoms, two singlets for non-functionalized quaternary carbon atoms, and one low field signal for the carbon atoms C2 and C7 in the 
amino groups in the ${ }^{13} \mathrm{C}$ NMR spectra. The presence of six naphthyl proton signals, six ${ }^{13} \mathrm{C}$ NMR signals for tertiary carbon atoms, and two ${ }^{13} \mathrm{C}$ NMR signals for functionalized quaternary carbon atoms with chemical shifts corresponding to carbons bonded to amino and hydroxy groups confirmed the formation of unsymmetrical monoaminated naphthalenes $\mathbf{5}$.

Our results together with the available published data suggested that the reaction of $\mathbf{1}$ with primary amines follows Scheme 2 . The process starts, similarly to the Bucherer reaction, ${ }^{6}$ with the concerted protonation of the carbon atoms with enhanced electron density in the naphthalene rings to give stabilized conjugated systems $\mathbf{a}$ and $\mathbf{b}$, which then react with the amine. In the subsequent transformations, the molecule loses aromaticity, which can be restored by two pathways (I, II).

According to one pathway (I), the electron density redistribution in intermediate $\mathbf{f}$ induces $\mathrm{C}$ $\mathrm{C}$ bond cleavage with elimination of water and formaldehyde to give two molecules of aminonaphthol $\mathbf{g}$, their subsequent amination resulting in diaminonaphthalene $\mathbf{h}$.

The second pathway (II) includes a rearrangement of intermediate f, resulting in the formation of a new C-C bond between the $2,2^{\prime}$-aminated $\alpha$-naphthalene moieties. This course of the process is possible if intermediate $\mathbf{f}$ has an additional pair of hydroxy groups in the 7,7'positions, which increase electron density at the $8,8^{\prime}$-carbon atoms located closely in space to the $1,1^{\prime}$-carbon atoms. Owing to the transannular interaction between the $1,8^{\prime}$ or $1^{\prime}, 8$ carbon atoms, a new $\mathrm{C}-\mathrm{C}$ bond is formed and a methylene unit is eliminated, giving rise to $1,8^{\prime}$-binaphthyl $\mathbf{l}$. The reaction ends in the aminolysis of the two remaining hydroxyl groups to give 1,1'-binaphthyl $\mathbf{m}$. With amines having bulky aliphatic N-substituents, which hamper the transannular interaction between the $1,8^{\prime}$ carbon atoms in intermediate $\mathbf{f}$, the reaction mainly follows pathway I.

The bifurcation of the reaction track and the route to binaphthyl $\mathbf{m}$ presented in Scheme 2 were confirmed by two additional experiments. First, we carried out amination of 2,7dihydroxynaphthalene $\mathbf{7}$ by aniline under the same conditions for 1,1-dinaphthylmethane $\mathbf{1}$ and showed that the reaction gives only one product, namely, 2,7-bis(phenylamino)naphthalene $\mathbf{3}$ (Scheme 3). Hence, under the conditions of aminolysis of compound 1 that we used, the formation of the new C-C bond cannot occur via cross-linking of two diaminonaphthalene $\mathbf{3}$ molecules.
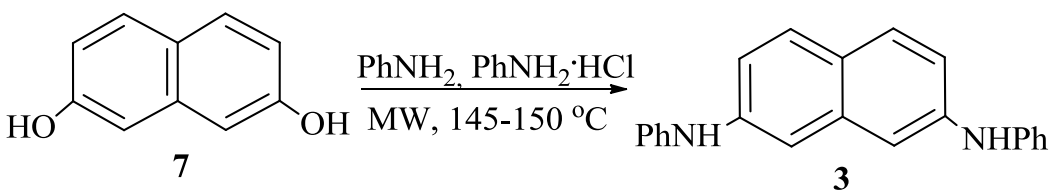

Scheme 3. Reaction of dihydroxynaphthalene 7 with aniline.

Second, we performed the reaction with aniline for 2,2'-dihydroxy-1,1-dinaphthylmethane (2), which has only one pair of hydroxy groups (Scheme 4). 


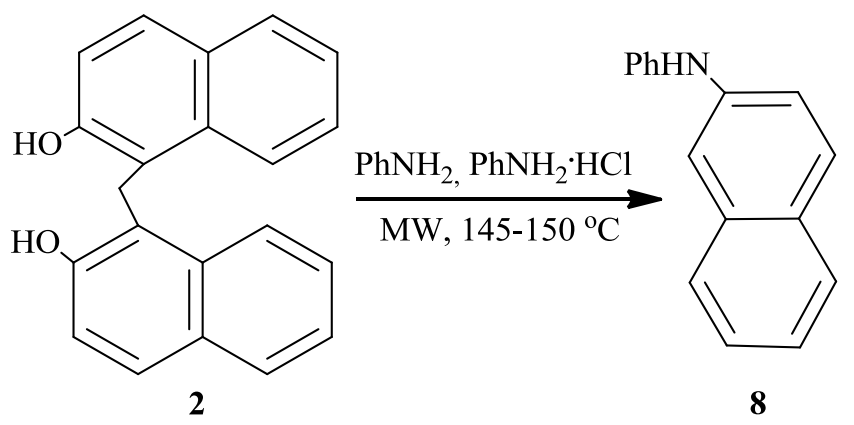

Scheme 4. Reaction of 2 with aniline.

As with the amination of tetrahydroxy-1,1-dinaphthylmethane 1, this reaction was accompanied by cleavage of bridging $\mathrm{C}-\mathrm{C}$ bonds but no cross-linking of the naphthalene rings took place, the process ending in the formation of 2-phenylaminonaphthalene (8). This fact confirms the effect of 7,7'-substituents in the molecule of 1,1-dinaphthylmethane $\mathbf{1}$ on the electron density redistribution in intermediate $\mathbf{f}$ (Scheme 2), and, hence, on the regiodirection of the whole process.

The reaction of 1,1-dinaphthylmethane $\mathbf{1}$ with ammonia was performed in a microwave reactor at $145-150{ }^{\circ} \mathrm{C}$ in the presence of ammonium sulfite. This reaction proceeded similarly to amination of 1 with aniline (Scheme 1). However, the high reactivity of the primary amino groups introduced in the naphthalene rings and the presence of formaldehyde formed upon elimination of the methylene unit (Scheme 2) changed the reaction pathway, giving rise to a third product, the diazepine derivative 11, which was formed in $36 \%$ yield (Scheme 5).

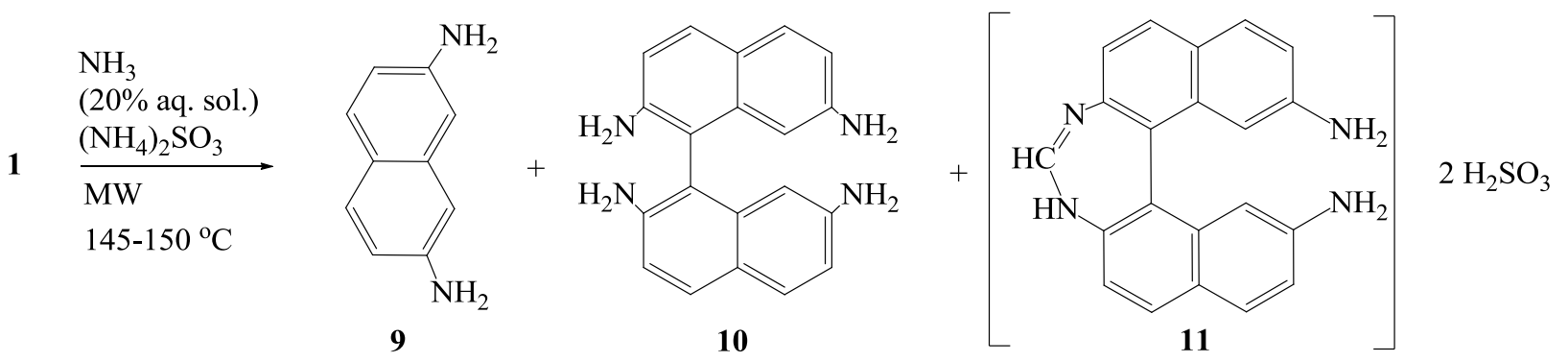

Scheme 5. Reaction of 1 with ammonia.

2,7-Diaminonaphthalene 9 and 2,2',7,7'-tetraamino-1,1'-binaphthyl $\mathbf{1 0}$ were isolated in $14 \%$ and $11 \%$ yields, respectively. The MALDI MS, IR, and ${ }^{1} \mathrm{H}$ and ${ }^{13} \mathrm{C}$ NMR data for compounds 9 , 10 were fully consistent with their compositions and structures.

The ${ }^{1} \mathrm{H}$ NMR spectrum of compound 11 exhibited four doublets for the H-(3-6) protons and a singlet for the H-8 protons of the naphthalene rings with the integrated intensity ratio $\mathrm{I}_{\mathrm{H}-3}: \mathrm{I}_{\mathrm{H}-4}: \mathrm{I}_{\mathrm{H}-}$ ${ }_{5}: \mathrm{I}_{\mathrm{H}-6}: \mathrm{I}_{\mathrm{H}-8} \cdot 1: 1: 1: 1: 1$, which proved the symmetric structure of the rigid cyclic system formed. In addition, a singlet for the proton at the imine carbon and a broadened NH proton signal were 
present in the low-field region. The ${ }^{13} \mathrm{C}$ NMR spectrum of $\mathbf{1 1}$ exhibited five singlets for tertiary carbon atoms and three signals for non-functionalized quaternary carbon atoms of the naphthalene rings; a signal for the tertiary carbon atom of the imine fragment; and low-field signals for quaternary carbon atoms bonded to amino (148.7 ppm) and imino (158 ppm) groups. The elemental analysis and MALDI MS data for compound $\mathbf{1 1}$ were fully consistent with the proposed diazepine structure.

Since direct amination of 2,2',7,7'-tetrahydroxy-1,1-dinaphthylmethane $\mathbf{1}$ with primary amines was accompanied by destruction of the molecular skeleton, its amino-containing derivatives were prepared using the approach $^{5 f-h}$ based on catalytic amination of $2,2^{\prime}, 7,7^{\prime}$ tetrakis(trifluoromethanesulfonyloxy)-1,1-dinaphthylmethane (12).

2,2',7,7'-Tetrakis(trifluoromethanesulfonyloxy)-1,1-dinaphthylmethane (12) was prepared by the reaction of 1 with trifluoromethanesulfonic anhydride in pyridine at $20-25{ }^{\circ} \mathrm{C}$ (Scheme 6).

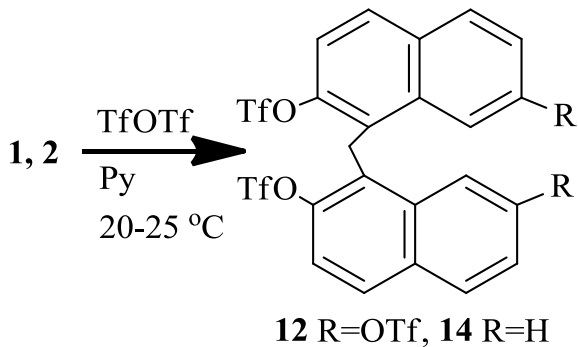

Scheme 6. Synthesis of oligo(trifluoromethanesulfonyloxy)-1,1-dinaphthylmethanes.

The ${ }^{1} \mathrm{H}$ NMR spectrum of 1,1-dinaphthylmethane $\mathbf{1 2}$ contained no hydroxyl proton signals but exhibited five doublets for the naphthalene protons and a singlet for the bridging methylene protons. The ${ }^{19} \mathrm{~F}$ NMR spectrum showed two singlets for the triflate fragments with close chemical shifts, -72.9 and $-73.2 \mathrm{ppm}$, while the ${ }^{13} \mathrm{C}$ NMR spectrum contained two low-field singlets with $\delta 146.4$ and $148.3 \mathrm{ppm}$ for the carbon atoms bonded to the triflate groups, which is due to the non-equivalence of the trifluoromethanesulfonyloxy fragments in positions 2 and 7. The reaction of tetratriflate 12 with aniline and hexylamine was performed at $110{ }^{\circ} \mathrm{C}$ in the presence of a catalyst $\left(\mathrm{Pd}(\mathrm{OAc})_{2}, \mathrm{BINAP}\right)$ and $\mathrm{Cs}_{2} \mathrm{CO}_{3}$. The reaction of $\mathbf{1 2}$ with aniline was selective, ending in the formation of 2,2'-di(trifluoromethanesulfonyloxy)-7,7'-di(phenylamino)1,1-dinaphthylmethane (13), which was isolated in 70\% yield (Scheme 7).

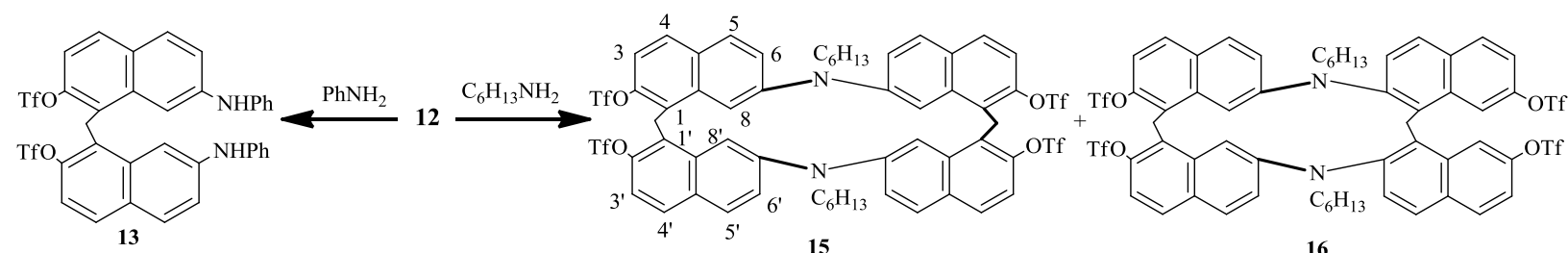

Scheme 7. Amination of tetratrifluoromethanesulfonyloxy-1,1-dinaphthylmethane $\mathbf{1 2}$ with aniline and hexylamine. Reaction conditions: BINAP, $\mathrm{Pd}(\mathrm{OAc})_{2}, \mathrm{Cs}_{2} \mathrm{CO}_{3}$, toluene, $110{ }^{\circ} \mathrm{C}$. 
The presence of ${ }^{1} \mathrm{H}$ and ${ }^{13} \mathrm{C}$ NMR signals for the methylene unit of compound $\mathbf{1 3}$ attested to the retained 1,1-dinaphthylmethane structure, while the integrated intensity ratio of the naphthalene and benzene ring proton signals and the MALDI MS data indicated that phenylamino groups were substituted for only two triflate fragments. The presence of one singlet at $-73.2 \mathrm{ppm}$ in the ${ }^{19} \mathrm{~F}$ NMR spectrum of 1,1-dinaphthylmethane $\mathbf{1 3}$ and the presence of one signal for carbon atom bound to the amino group ( $\delta 143.1 \mathrm{ppm})$ and one for carbon bound to the triflate group ( $\delta 146.3 \mathrm{ppm})$ in the ${ }^{13} \mathrm{C}$ NMR spectrum suggested that the substitution involved equivalent carbon atoms, either in $2,2^{\prime}$ or in $7,7^{\prime}$ positions.

This issue was clarified by a special experiment. We trifluoromethaneulfonylated 2,2'dihydroxy-1,1-dinaphthylmethane (2) under conditions used for the synthesis of compound $\mathbf{1 2}$ (Scheme 6). The chemical shift (-73.2 ppm) of the singlet recorded in the ${ }^{19} \mathrm{~F}$ NMR spectrum of 2,2'-ditrifluoromethanesulfonyloxy-1,1'-dinaphthylmethane (14) was identical to that observed for diamine 13, and the ${ }^{13} \mathrm{C}$ NMR chemical shift of 2,2'-carbons attached to the triflate groups in compound $14(145.6 \mathrm{ppm})$ was similar to the low-field signal $(146.3 \mathrm{ppm})$ present in the spectrum of 13. The foregoing indicates that amination of tetratriflate 12 involved more open 7,7' positions. An additional piece of evidence for this conclusion is the absence of reaction between ditriflate $\mathbf{1 4}$ and aniline under tetratriflate $\mathbf{1 2}$ amination conditions.

The reaction of tetratrifluoromethanesulfonyloxy-1,1-dinaphthylmethane $\mathbf{1 2}$ with hexylamine was much less selective than the reaction with aniline. Apparently, in this case, triflate fragments were replaced by amino groups non-selectively. The products obtained had functional groups in various ratios and in various positions. In addition, the reaction may give cyclic and oligomeric derivatives. Using column chromatography, two products $\mathbf{1 5}$ and $\mathbf{1 6}$ were isolated in a pure state in 6.5 and $10 \%$ yields, respectively (Scheme 7).

Elemental analysis, mass spectrometry, and NMR data suggest that both products are macroheterocyclic compounds with nitrogen-containing spacers but with different modes of coupling of the ditrifluoromethanesulfonyloxy-1,1-dinaphthylmethane fragments.

The ${ }^{19} \mathrm{~F}$ and ${ }^{13} \mathrm{C}$ NMR spectra of macrocycle $\mathbf{1 5}$ each showed one signal for $\mathrm{F}$ and $\mathrm{C}$ atoms of the trifluoromethyl groups. In the ${ }^{13} \mathrm{C}$ NMR spectrum of $\mathbf{1 5}$, ten carbon signals for the naphthalene rings were recorded, in particular, the singlets for C-2 attached to the triflate groups and C-7 attached to nitrogen spacers, three signals for the other quaternary $\mathrm{C}$ atoms, and five signals for tertiary $\mathrm{C}$ atoms.

The ${ }^{1} \mathrm{H}$ NMR spectrum of $\mathbf{1 5}$ exhibited five signals for the aromatic protons with equal integrated intensities. This attested to a symmetric structure of molecule 15, suggesting that the heterocycle has resulted from the reaction of hexylamine with the C-7 atoms of two 1,1dinaphthylmethane molecules $\mathbf{1 2}$.

In the ${ }^{19} \mathrm{~F}$ NMR spectrum of macrocycle 16, three singlets for triflate $\mathrm{F}$ atoms were recorded. The ${ }^{13} \mathrm{C}$ NMR spectrum of $\mathbf{1 6}$ contained two quartets for triflate $\mathrm{C}$ atoms and four signals for the naphthalene-ring carbons $(\mathrm{C}-2,7)$ attached to functional groups. In addition, both ${ }^{13} \mathrm{C}$ and ${ }^{1} \mathrm{H}$ NMR signals of the aromatic nuclei of $\mathbf{1 6}$ were doubled. This demonstrated the chemical nonequivalence of the ditrifluoromethanesulfonyloxy-1,1-dinaphthylmethane fragments in $\mathbf{1 6}$ and 
implied that the heterocycle may have formed through the reaction of hexylamine with the C-2 atoms of one 1,1-dinaphthylmethane $\mathbf{1 2}$ molecule and the C-7 atoms of the other molecule.

In summary, the route of the reaction of oligohydroxy-1,1-dinaphthylmethanes with primary amines and ammonia differs from that of the naphthol amination processes described earlier. ${ }^{5}$ The replacement of the hydroxy groups in 2,2'-dihydroxy- and 2,2',7,7'-tetrahydroxy-1,1dinaphthylmethanes by amino groups is accompanied by $\mathrm{C}-\mathrm{C}$ bond cleavage and elimination of the methylene unit. The catalytic amination of 2,2',7,7'-tetratrifluoromethanesulfonyloxy-1,1dinaphthylmethane does not involve destruction of the aromatic core and affords oligofunctionalized derivatives of various types, including macrocyclic 1,1-dinaphthylmethane systems with nitrogen-containing spacers.

\section{Experimental Section}

General. All microwave irradiation experiments were carried out in a Focused Microwave ${ }^{\mathrm{TM}}$ Synthesis System Discover CEM "Discover", operating at a frequency of $2.45 \mathrm{GHz}$ with continuous irradiation power from 50 to $150 \mathrm{~W} .{ }^{1} \mathrm{H},{ }^{13} \mathrm{C}$ NMR (TMS as an internal standard), ${ }^{19} \mathrm{~F}$ NMR (trifluoroacetic acid as external standard) were recorded on a Jeol ECX-400 spectrometer operating at $400 \mathrm{MHz}$ for ${ }^{1} \mathrm{H}, 100.5 \mathrm{MHz}$ for ${ }^{13} \mathrm{C}$, and $376.2 \mathrm{MHz}$ for ${ }^{19} \mathrm{~F}$. The signals of 3-6, 916 were assigned using $\mathrm{H}-\mathrm{H}$ homonuclear double resonance (proton spin decoupling). The full assignment of the signals of compounds $4,5 \mathbf{b}-\mathbf{c}, \mathbf{6 b}, \mathbf{8}, \mathbf{1 1}, \mathbf{1 2 - 1 6}$ was based on ${ }^{1} \mathrm{H} /{ }^{13} \mathrm{C} 2 \mathrm{D}$ corelation. IR spectra were measured on a Thermo NICOLETE 380 spectrometer in the reflection mode in the $4000-500 \mathrm{~cm}^{-1}$ range on ZnSe glass. Elemental analysis was performed on Thermo Flash EA112 CHN Elemental analyzer. 2,2',7,7'-Tetrahydroxy-1,1-dinaphthylmethane 1 and 2,2'-dihydroxy-1,1-dinaphthylmethane 2 were prepared by reported procedures. ${ }^{2 \mathrm{~b}, 7}$

Reaction of tetrahydroxy-1,1-dinaphthylmethane $\mathbf{1}$ with aniline. A mixture of $\mathbf{1}(0.4 \mathrm{~g}, 1.2$ $\mathrm{mmol})$, aniline $(1.6 \mathrm{~g}, 16.8 \mathrm{mmol})$ and aniline hydrochloride $(0.93 \mathrm{~g}, 7.2 \mathrm{mmol})$ was heated for 2 $\mathrm{h}$ at $145-150{ }^{\circ} \mathrm{C}$ in a microwave reactor. After cooling, the reaction mixture was neutralized with aqueous alkali $(\mathrm{NaOH})(0.67 \mathrm{~g}$ in $50 \mathrm{~mL}$ of water). Aniline was steam-distilled. The precipitated products were filtered off, washed with water, dissolved in benzene $(1 \mathrm{~mL})$, and separated by column chromatography (silica gel, benzene). Benzene was distilled off and the residue was dried at $100-110{ }^{\circ} \mathrm{C}(1 \mathrm{~mm} \mathrm{Hg})$.

2,7-Bis(phenylamino)naphthalene (3). Purplish blue powder. Yield $0.03 \mathrm{~g}$ (5\%). mp158-159 ${ }^{\circ} \mathrm{C} .{ }^{1} \mathrm{H}$ NMR (acetone-d ${ }_{6}$ ), $\delta$, ppm: 6.88 (tt, 2H, J.7.4, $2.4 \mathrm{~Hz}, \mathrm{H}-\mathrm{pPh}$ ), 7.09 (dd, 2H, J.8.8, 2.2 Hz, H-3,6), 7.22-7.30 (m, 8H, H-o, $m$ Ph), 7.35 (d, 2H, J.2.2 Hz, H-1,8), 7.56 (br.s, 2H, NH), 7.64 (d, 2H, J.8.8 Hz, H-4,5). ${ }^{13} \mathrm{C}$ NMR $\left(\mathrm{CDCl}_{3}\right), \delta$, ppm: 108.9 (C-1 or C-8), 109.2 (C-1 or C-8), 117.0 (C-3 or C-6), 117.3 (C-3 or C-6), 117.7 (C-oPh), 117.9 (C-oPh), 120.4 (C-pPh), 120.6 (C$p \mathrm{Ph}), 124.5$ (C-9), 128.7 (C-4 or C-5), 128.8 (C-4 or C-5), 129.1 (C-mPh), 129.4 (C-mPh), 136.4 
(C-10), 142.1 (C-iPh), 143.7 (s, C-2,7). MS (MALDI, TOF), m/z: 309 [M- $\left.\mathrm{H}^{+}\right], 310$ [M+ $\mathrm{M}^{+}$For $\mathrm{C}_{22} \mathrm{H}_{18} \mathrm{~N}_{2}$, calcd., \%: C 85.13; H 5.85; N 9.03. Found, \%: C 84.96; H 5.82; N 9.22.

2,2',7,7'-Tetrakis(phenylamino)-1,1'-binaphthyl (4). Green powder. Yield $0.44 \mathrm{~g}$ (58\%). mp138-140 ${ }^{\circ}$. ${ }^{1} \mathrm{H}$ NMR $\left(\mathrm{CDCl}_{3}\right), \delta$, ppm: 5.81 (br.s, 4H, NH), 6.99 (tt, 4H, J.7.4, 2.4 Hz, HpPh), 7.03 (d, 2H, J.8.7 Hz, H-3), 7.04 (dd, 2H, J =8.8, 2.2 Hz, H-6), 7.16 (d, 8H, J.8.7 Hz, H$o \mathrm{Ph}), 7.25$ (d, 2H, J.2.2 Hz , H-8), 7.31 (dd, 8H, J.8.7, 7.4 Hz, H-mPh), 7.64 (d, 4H, J.8.8 Hz, H4,5). ${ }^{13} \mathrm{C}$ NMR $\left(\mathrm{CDCl}_{3}\right), \delta$, ppm: $110.2(\mathrm{C}-8), 117.6(\mathrm{C}-3,6), 118.5(\mathrm{C}-o \mathrm{Ph}), 121.4(\mathrm{C}-p \mathrm{Ph})$, 124.9 (C-9), 128.6 (C-1), 129.1 (C-4,5), 129.5 (C-mPh), 136.0 (C-10), 141.6 (C-iPh), 142.9 (C2,7). IR (Neat) $\mathrm{cm}^{-1}:$ 3412.4, 3395.2, 1628.2, 1596.6, 1501.2, 1303.5, 1165.4, 871.0, 840.0, 819.5, 730.5, 687.1. MS (MALDI-TOF), $m / z$ : $618\left[\mathrm{M}^{+}\right], 619\left[\mathrm{M}+\mathrm{H}^{+}\right]$. For $\mathrm{C}_{44} \mathrm{H}_{34} \mathrm{~N}_{4}$, calcd., \%: C 85.41; H 5.54; N 9.05. Found, \%: C 85.45; H 5.73; N 8.82.

\section{Reaction of tetrahydroxy-1,1-dinaphthylmethane 1 with aliphatic amines. General procedure}

A mixture of $1(0.7 \mathrm{mmol})$, primary amine $(9.5 \mathrm{mmol})$, and amine hydrochloride $(4.3 \mathrm{mmol})$ was heated for $6 \mathrm{~h}$ (sec-butylamine), 11 and $30 \mathrm{~h}$ (cyclohexylamine), $4 \mathrm{~h}$ (hexylamine) at 145-150 ${ }^{\circ} \mathrm{C}$. The resulting oil was dissolved in acetone $(0.4 \mathrm{~mL})$. The precipitated amine hydrochloride was filtered off and washed with acetone, and the solvent was distilled off. The products were separated by column chromatography (silica gel, hexane, hexane : dioxane.10:1, then hexane : dioxane.3:1), the solvents were distilled off, and the residues were dried at $100-110{ }^{\circ} \mathrm{C}(1 \mathrm{~mm}$ $\mathrm{Hg})$.

7-sec-Butylaminonaphth-2-ol (5a). Brown oil. Yield $0.02 \mathrm{~g}(8 \%) .{ }^{1} \mathrm{H}$ NMR (acetone- $\left.\mathrm{d}_{6}\right), \delta$, ppm: 0.95 (t, 3H, J=7.3 Hz, $\left.\mathrm{CH}_{3}\right), 1.16\left(\mathrm{~d}, 3 \mathrm{H}, J .6 .4 \mathrm{~Hz}, \mathrm{CH}_{3}\right), 1.46-1.68\left(\mathrm{~m}, 2 \mathrm{H}, \mathrm{CH}_{2}\right), 3.42-$ 3.58 (m, 1H, CH), 4.81 (br.s, 1H, NH), 6.56 (d, 1H, J.2.3 Hz, H-8), 6.69 (dd, 1H, J.8.7, 2.3 Hz, H-6), 6.72 (dd, 1H, J.8.7, 2.3 Hz, H-3), 6.88 (d, 1H, J.2.3 Hz, H-1), 7.42 (d, 1H, J.8.7 Hz, H-4), 7.44 (d, 1H, J.8.7 Hz, H-5), 8.53 (br.s, 1H, OH). ${ }^{13} \mathrm{C}$ NMR (acetone-d 6 ) $\delta$, ppm: $9.9\left(\mathrm{CH}_{3}\right), 19.6$ $\left(\mathrm{CH}_{2}\right), 49.4(\mathrm{CH}), 102.3$ (C-8), 107.2 (C-1), 113.3 (C-3), 115.6 (C-6), 122.0 (C-9), 128.4 (C-4), 128.9 (C-5), 137.4 (C-10), 146.6 (C-7), 155.8 (C-2). MS (MALDI-TOF), m/z: 215 [M ${ }^{+}$. For $\mathrm{C}_{14} \mathrm{H}_{17} \mathrm{NO}$, calcd. \%: C 78.10; H 7.96; N 6.51. Found, \%: C 78.09; H 7.98; N 6.46.

2,7-Bis(sec-butylamino)naphthalene (6a). Brown oil. Yield $0.09 \mathrm{~g}(24 \%) .{ }^{1} \mathrm{H}$ NMR (acetone$\mathrm{d}_{6}$ ), $\delta$, ppm: $0.95\left(\mathrm{t}, 6 \mathrm{H}, J .7 .3 \mathrm{~Hz}, \mathrm{CH}_{3}\right), 1.16\left(\mathrm{~d}, 6 \mathrm{H}, J .6 .4 \mathrm{~Hz}, \mathrm{CH}_{3}\right), 1.45-1.70\left(\mathrm{~m}, 4 \mathrm{H}, \mathrm{CH}_{2}\right)$, 3.45-3.55 (m, 2H, CH), 4.63 (br.s, 2H, NH), 6.53 (d, 2H, J.2.3 Hz, H-1,8), 6.57 (dd, 2H, J =8.7, $2.3 \mathrm{~Hz}, \mathrm{H}-3,6), 7.31(\mathrm{~d}, 2 \mathrm{H}, J .8 .7 \mathrm{~Hz}, \mathrm{H}-4,5) .{ }^{13} \mathrm{C}$ NMR (acetone-d 6 ) $\delta, \mathrm{ppm}: 10.0\left(\mathrm{CH}_{3}\right), 19.6$ $\left(\mathrm{CH}_{2}\right), 49.4(\mathrm{CH}), 102.5$ (C-1,8), 113.8 (C-3,6), 120.7 (C-9), 128.3 (C-4,5), 137.7 (C-10), 146.5 (C-2,7). MS (MALDI-TOF), m/z: 270[M $\mathrm{M}^{+}$. For $\mathrm{C}_{18} \mathrm{H}_{26} \mathrm{~N}_{2}$, calcd. \%: C 79.95; H 9.69; N 10.36. Found, \%: C 80.01; H 9.71; N 10.28.

7-Cyclohexylaminonaphth-2-ol (5b). Cherry-colored oil. Yield $0.08 \mathrm{~g}(23 \%)(11 \mathrm{~h}) .{ }^{1} \mathrm{H}$ NMR (acetone- $\left.\mathrm{d}_{6}\right), \delta$, ppm: 1.15-1.28 (m, $\left.3 \mathrm{H}, \mathrm{CH}_{2}{ }^{\mathrm{e}}\right), 1.35-1.47\left(\mathrm{~m}, 2 \mathrm{H}, \mathrm{CH}_{2}{ }^{\mathrm{e}}\right), 1.59-1.67(\mathrm{~m}, 1 \mathrm{H}$, $\left.\mathrm{CH}_{2}{ }^{\mathrm{a}}\right), 1.71-1.79\left(\mathrm{~m}, 2 \mathrm{H}, \mathrm{CH}_{2}{ }^{\mathrm{a}}\right), 2.01-2.03\left(\mathrm{~m}, 2 \mathrm{H}, \mathrm{CH}_{2}{ }^{\mathrm{a}}\right), 3.31-3.39(\mathrm{~m}, 1 \mathrm{H}, \mathrm{CH}), 4.83$ (br.s, $1 \mathrm{H}$, NH), 6.61 (d, 1H, J.2.2 Hz, H-8), 6.70 (dd, 1H, J.8.9, 2.2 Hz, H-6), 6.72 (dd, 1H, J.8.9, 2.2 Hz, 
H-3), 6.88 (d, 1H, J.2.2 Hz, H-1), 7.42 (d, 1H, J.8.9 Hz, H-4), 7.46 (d, 1H, J.8.9 Hz, H-5), 8.23 (s, 1H, OH). ${ }^{13} \mathrm{C}$ NMR (acetone-d $\left.{ }_{6}\right) \delta$, ppm: $24.9\left(\mathrm{CH}_{2}\right), 25.9\left(\mathrm{CH}_{2}\right), 33.0\left(\mathrm{CH}_{2}\right), 51.2(\mathrm{CH})$, 102.4 (C-8), 107.3 (C-1), 113.2 (C-6), 115.6 (C-3), 122.1 (C-9), 128.5 (C-5), 129.1 (C-4), 137.4 (C-10), 146.2 (C-7), 155.7 (C-2). IR (Neat), $\mathrm{cm}^{-1}$ : 2928.6, 2851.0, 1627.3, 1486.3, 1449.4, 1358.2, 1209.9, 1171.0, 1141.7, 1081.0, 886.4, 833.6, 796.5, 622.1, 537.1. MS (MALDI-TOF), m/z: $241\left[\mathrm{M}^{+}\right]$. For $\mathrm{C}_{16} \mathrm{H}_{19} \mathrm{NO}$, calcd. \%: C 79.63; H 7.94; N 5.80. Found, \%: C 79.61; H 7.90; N 5.84 .

2,7-Bis(cyclohexylamino)naphthalene (6b). Cherry-colored oil. Yield $0.05 \mathrm{~g}(11 \%)(11 \mathrm{~h}), 0.07$ $\mathrm{g}(21 \%)(30 \mathrm{~h}):{ }^{1} \mathrm{H}$ NMR (acetone- $\left.\mathrm{d}_{6}\right), \delta$, ppm: 1.14-1.28 (m, 6H, $\left.\mathrm{CH}_{2}{ }^{\mathrm{e}}\right), 1.34-1.47$ (m, 4H, $\left.\mathrm{CH}_{2}{ }^{\mathrm{e}}\right), 1.59-1.67\left(\mathrm{~m}, 2 \mathrm{H}, \mathrm{CH}_{2}{ }^{\mathrm{a}}\right), 1.71-1.79\left(\mathrm{~m}, 4 \mathrm{H}, \mathrm{CH}_{2}{ }^{\mathrm{a}}\right), 2.06-2.09\left(\mathrm{~m}, 4 \mathrm{H}, \mathrm{CH}_{2}{ }^{\mathrm{a}}\right), 3.33-3.35$ (m, 2H, CH), 4.55 (br.s, 2H, NH), 6.54 (d, 2H, J.8.7 Hz, H-3,6), 6.56 (d, 2H, J.2.3 Hz, H-1,8), 7.29 (d, 2H, J.8.9 Hz, H-4,5). ${ }^{13} \mathrm{C}$ NMR (acetone-d $\left.)_{6}\right) \delta$, ppm: $25.0\left(\mathrm{CH}_{2}\right), 26.0\left(\mathrm{CH}_{2}\right), 33.1$ $\left(\mathrm{CH}_{2}\right), 51.2(\mathrm{CH}), 102.5$ (C-3,6), 113.8 (C-1,8), 120.7 (C-9), 128.3 (C-4,5), 137.7 (C-10), 146.1 (C-2,7). IR (Neat), $\mathrm{cm}^{-1}$ : 3378.0, 2923.8, 2851.0, 1625.0, 1524.7, 1448.1, 816.3, 519.2. MS (MALDI-TOF), $m / z: 322\left[\mathrm{M}^{+}\right]$. For $\mathrm{C}_{22} \mathrm{H}_{30} \mathrm{~N}_{2}$, calcd. \%: C 81.94; H 9.38; N 8.69. Found, \%: C 81.98; H 9.41; N 8.61.

2,7-Bis(hexylamino)naphthalene (6c). Beige-colored powder. Yield $0.14 \mathrm{~g} \mathrm{(35 \% ).} \mathrm{mp72-73}{ }^{\circ} \mathrm{C}$. ${ }^{1} \mathrm{H} \quad \mathrm{NMR}$ (acetone- $\mathrm{d}_{6}$ ), $\delta$, ppm: $0.87 \quad\left(\mathrm{t}, \quad 6 \mathrm{H}, \quad J .7 .1 \mathrm{~Hz}, \mathrm{CH}_{3}\right), \quad 1.25-1.38 \quad(\mathrm{~m}, \quad 8 \mathrm{H}$, $\left.\left(\mathrm{CH}_{2}\right)_{3} \underline{\mathrm{CH}_{2}} \underline{\mathrm{CH}}_{2} \mathrm{CH}_{3}\right), \quad 1.41-1.48 \quad\left(\mathrm{~m}, \quad 4 \mathrm{H}, \quad\left(\mathrm{CH}_{2}\right)_{2} \underline{\mathrm{CH}}_{2}\left(\mathrm{CH}_{2}\right)_{2} \mathrm{CH}_{3}\right), \quad 1.60-1.70 \quad(\mathrm{~m}, \quad 4 \mathrm{H}$, $\left.\mathrm{CH}_{2} \mathrm{CH}_{2}\left(\mathrm{CH}_{2}\right)_{3} \mathrm{CH}_{3}\right), 3.13$ (t, $4 \mathrm{H}$, J.7.1 Hz, $\left.\underline{\mathrm{CH}}_{2} \mathrm{CH}_{2}\left(\mathrm{CH}_{2}\right)_{3} \mathrm{CH}_{3}\right), 4.84$ (br.s, 2H, NH), 6.53 (d, 2H, J.1.8 Hz, H-1,8), 6.58 (dd, 2H, J.8.7, $1.8 \mathrm{~Hz}, \mathrm{H}-3,6), 7.31$ (d, 2H, J.8.7 Hz, H-4,5). ${ }^{13} \mathrm{C}$ NMR (acetone-d $\left.{ }_{6}\right) \delta$, ppm: $13.6\left(\mathrm{CH}_{3}\right), 22.6\left(\mathrm{CH}_{2}\right), 26.9\left(\mathrm{CH}_{2}\right), 29.3\left(\mathrm{CH}_{2}\right), 31.6\left(\mathrm{CH}_{2}\right), 43.5\left(\mathrm{CH}_{2}\right)$, 101.9 (C-1,8), 113.5 (C-3,6), 120.8 (C-9), 128.2 (C-4,5), 137.7 (C-10), 147.3 (C-2,7). IR (Neat), $\mathrm{cm}^{-1}: 3687.2,3674.7,3362.3,2963.5,2923.0,1632.2,1509.2,1464.8,1406.2,1296.8,1250.9$, 1224.6, 1054.1, 883.0, 816.7, 649.6, 613.1, 536.9. MS (MALDI-TOF), m/z: 326[M $\left.{ }^{+}\right]$. For $\mathrm{C}_{22} \mathrm{H}_{34} \mathrm{~N}_{2}$, calcd., \%: C 80.93; H 10.50; N 8.58. Found, \%: C 80.56; H 10.36; N 8.21.

Reaction of 2,7-dihydroxynaphthalene 7 with aniline was carried out similarly to amination of 1 with aniline using a mixture of dihydroxynaphthalene 7 (1.13 g, $7.1 \mathrm{mmol})$, aniline $(4.6 \mathrm{~g}, 49.5$ $\mathrm{mmol})$, and aniline hydrochloride (1.83 $\mathrm{g}, 14.1 \mathrm{mmol})$.

2,7-Di(phenylamino)naphthalene (3). Purplish blue powder. Yield: $1.99 \mathrm{~g}$ (91\%). mp158-159 ${ }^{\circ} \mathrm{C}$. MS (MALDI-TOF), m/z: $309\left[\mathrm{M}^{+}\right]$. For $\mathrm{C}_{22} \mathrm{H}_{18} \mathrm{~N}_{2}$, calcd. \%: C 85.13; H 5.85; N 9.03. Found, $\%$ : C 84.96; H 5.82; N 9.22.

Reaction of 2,2'-dihydroxy-1,1-dinaphthylmethane 2 with aniline was carried out similarly to amination of 1 with aniline using a mixture of $2(0.23 \mathrm{~g}, 0.8 \mathrm{mmol})$, aniline $(0.44 \mathrm{~g}, 4.7 \mathrm{mmol})$, and aniline hydrochloride $(0.20 \mathrm{~g}, 1.6 \mathrm{mmol})$.

2-Phenylaminonaphthalene (8). Pale orange powder. Yield $0.15 \mathrm{~g}(43 \%) . \mathrm{mp} 107-109{ }^{\circ} \mathrm{C} .{ }^{1} \mathrm{H}$ NMR (acetone-d $\mathrm{d}_{6}$ ), $\delta$, ppm: 6.91 (tt, 1H, J.6.9, $\left.2.3 \mathrm{~Hz}, \mathrm{H}-p \mathrm{Ph}\right), 7.21-7.25$ (m, 1H, H-6), 7.25 (d, 2H, J.6.9 Hz, H-oPh), 7.27 (t, 2H, J.6.9, 6.9 Hz, H-mPh), 7.31 (dd, 1H, J.6.9, 2.3 Hz, H-3), 7.36 
(tt, 1H, J.6.9, 0.9 Hz, H-7), 7.64 (s, 1H, NH), 7.52 (d, 1H, J.2.3 Hz, H-1), 7.66 (d, 1H, J.7.8 Hz, $\mathrm{H}-8), 7.73$ (d, 1H, J.6.9 Hz, H-5), 7.76 (d, $1 \mathrm{H}, J .6 .9 \mathrm{~Hz}, \mathrm{H}-4) .{ }^{13} \mathrm{C}$ NMR (acetone-d ${ }_{6}$ ), $\delta$, ppm: 110.0 (C-1), 117.9 (C-oPh), 120.1 (C-3), 120.8 (C-pPh), 123.1 (C-6), 126.4 (C-7), 126.4 (C-8), 127.7 (C-5), 129.06 (C-10), 129.09 (C-4), 129.4 (C- $m$ Ph), 135.1 (C-9), 141.8 (C-2), 143.5 (C$i \mathrm{Ph})$. IR (Neat), $\mathrm{cm}^{-1}: 3391.6,3050.4,1626.1,1594.9,1494.4,1413.2,1302.4,853.0,817.4$, 735.6, 689.0. MS (MALDI), $m / z: 218\left[\mathrm{M}^{+}\right] . \mathrm{C}_{16} \mathrm{H}_{13} \mathrm{~N}$. Published data: $\mathrm{mp} 107-109^{\circ} \mathrm{C}^{8}$.

Reaction of tetrahydroxy-1,1-dinaphthylmethane 1 with ammonia. A mixture of $\mathbf{1}(0.11 \mathrm{~g}$, $0.3 \mathrm{mmol})$, ammonium sulfite $(0.29 \mathrm{~g}, 2.5 \mathrm{mmol})$ and ammonia $(0.06 \mathrm{~g}, 3.8 \mathrm{mmol}, 20 \% \mathrm{aq}$. solution) was heated with stirring at $145-150{ }^{\circ} \mathrm{C}$ for $7 \mathrm{~h}$. The precipitated compound 11 was filtered off, washed with acetone and dried at $100-110{ }^{\circ} \mathrm{C}(1 \mathrm{~mm} \mathrm{Hg})$. The solvent was distilled off from the filtrate, acetone $(1 \mathrm{~mL})$ was added to the residue, the precipitated ammonium bisulfite was filtered off, and acetone was distilled off. The products were separated using column chromatography (silica gel, benzene, benzene : dioxane.5: 1).

2,7-Diaminonaphthalene (9). Dark yellow oil. Yield $0.02 \mathrm{~g}(14 \%) .{ }^{1} \mathrm{H}$ NMR (acetone- $\mathrm{d}_{6}$ ), $\delta$, ppm: 6.89 (dd, 2H, J.8.9, 2.3 Hz, H-3,6), 6.96 (d, 2H, J.2.3 Hz, H-1,8), 7.60 (d, 2H, J.8.9 Hz, H4,5), 8.43 (s, 4H, NH). ${ }^{13} \mathrm{C}$ NMR (acetone- $\left.\mathrm{d}_{6}\right) \delta$, ppm: $107.6(\mathrm{C}-1,8), 115.3(\mathrm{C}-3,6), 128.44(\mathrm{C}-$ 9), 129.4 (C-4,5), 136.8 (C-10), 155.8 (C-2,7). IR (Thin film), $\mathrm{cm}^{-1}: 3309.0,2923.3,1630.3$, 1517.0, 1461.5, 1358.3, 1293.8, 1189.0, 876.1, 831.4, 800.7, 631.7, 473.2. MS (MALDI-TOF), $m / z: 160\left[\mathrm{M}+2 \mathrm{H}^{+}\right]$. For $\mathrm{C}_{10} \mathrm{H}_{10} \mathrm{~N}_{2}$, calcd., \%: C 75.92; H 6.37; N 17.71. Found, \%: $\mathrm{C} 75.88 ; \mathrm{H}$ $6.34 ; \mathrm{N} 17.78$.

2,2',7,7'-Tetraamino-1,1'-binaphthyl (10). Brown oil. Yield $0.01 \mathrm{~g}(11 \%) .{ }^{1} \mathrm{H}$ NMR (acetone$\mathrm{d}_{6}$ ), $\delta$, ppm: 6.89 (dd, 2H, J.8.9, 2.3 Hz, H-6), 6.94 (d, 2H, J.8.9 Hz, H-3), 7.16 (d, 2H, J.2.3 Hz, H-8), 7.46 (d, 2H, J.8.9 Hz, H-4), 7.60 (d, 2H, J.8.9 Hz, H-5), 8.43 (br.s, 8H, NH). ${ }^{13} \mathrm{C}$ NMR (acetone- $\mathrm{d}_{6}$ ), $\delta$, ppm: 104.9 (C-8), 114.6 (C-3 or C-6), 114.8 (C-3 or C-6), 120.3 (C-1), 126.8 (C4 or C-5), 128.3 (C-9), 129.9 (C-4 or C-5), 136.0 (C-10), 145.3 (C-7), 152.5 (C-2). IR (Neat), $\mathrm{cm}^{-1}: 3342.4,2942.0,2887.8,1715.0,1362.7,1222.3,1111.0,1040.3,924.0,848.8$. MS (MALDI-TOF), m/z: $312\left[\mathrm{M}-2 \mathrm{H}^{+}\right]$. For $\mathrm{C}_{20} \mathrm{H}_{18} \mathrm{~N}_{4}$, calcd. \%: C 76.41; $\mathrm{H}$ 5.77; N 17.82. Found, \%: C 76.45; H 5.76; N 17.79.

2,14-Diamino-9H-dinaphtho[2,1-d:1',2'-f]1,3-diazepine bis(sulfuric acid) salt (11). Green powder. Yield $0.06 \mathrm{~g}(36 \%)$ mp> $360{ }^{\circ} \mathrm{C} .{ }^{1} \mathrm{H}$ NMR (DMSO-d 6 ), $\delta$, ppm: 7.24 (d, 2H, J.8.7 Hz, H-6), 7.74 (d, 2H, J.8.9 Hz, H-3), 7.86 (d, 2H, J.8.7 Hz, H-5), 7.98 (d, 2H, J.8.9 Hz, H-4), 8.45 (s, $1 \mathrm{H}, \mathrm{H}-8$ ), 10.02 (br.s, $5 \mathrm{H}, \mathrm{NH}$ ), $10.16\left(\mathrm{~s}, 1 \mathrm{H}, \mathrm{CH}=\mathrm{N}\right.$ ). ${ }^{13} \mathrm{C}$ NMR (DMSO-d $\left.\mathrm{d}_{6}\right) \delta$, ppm: 108.7 (C-1), 108.9 (C-8), 117.7 (C-9), 118.4 (C-6), 123.1 (C-10), 124.8 (C-3), $126.4(\mathrm{CH}=\mathrm{N}), 130.7$ (C-5), 132.4 (C-4), 148.7 (C-7), 158.0 (C-2). IR (Neat), $\mathrm{cm}^{-1}$ : 3195.7, 3016.2, 2570.8, 1608.3, 1578.3, 1520.5, 1502.8, 1432.2, 1389.4, 1314.4, 1269.4, 1217.9, 1090.8, 902.1, 882.1, 852.6, 832.7, 752.4, 591.9, 522.3. MS (MALDI-TOF), m/z: $484\left[\mathrm{M}^{+}\right]$. For $\mathrm{C}_{21} \mathrm{H}_{20} \mathrm{~N}_{4} \mathrm{O}_{6} \mathrm{~S}_{2}$, calcd. \%: C 51.63; H 4.13; N 11.47. Found, \%: C 51.35; H 4.49; N 11.20. 


\section{2,2',7,7'-Tetrakis(trifluoromethanesulfonyloxy)-1,1-dinaphthylmethane (12).}

Trifluoromethane-sulfonic anhydride $(0.79 \mathrm{~g}, 2.8 \mathrm{mmol})$ was added dropwise to a solution of 1,1-dinaphthylmethane $1(0.12 \mathrm{~g}, 0.3 \mathrm{mmol})$ in pyridine $(3 \mathrm{~mL})$ cooled down to $0{ }^{\circ} \mathrm{C}$. The reaction mixture was kept for $24 \mathrm{~h}$ at $20-25^{\circ} \mathrm{C}$, and water $(20 \mathrm{~mL})$ was added. The precipitate that formed was filtered off, washed with $5 \%$ hydrochloric acid and with water to neutral $\mathrm{pH}$, and dried at $80-90{ }^{\circ} \mathrm{C}(1 \mathrm{~mm} \mathrm{Hg})$. Light yellow powder. Yield $0.20 \mathrm{~g}(67 \%) . \mathrm{mp} 113-114{ }^{\circ} \mathrm{C} .{ }^{1} \mathrm{H}$ NMR $\left(\mathrm{CDCl}_{3}\right), \delta$, ppm: $5.01\left(\mathrm{~s}, 2 \mathrm{H}, \mathrm{CH}_{2}\right), 7.35$ (dd, 2H, J.9.20, 2.30 Hz, H-6), 7.58 (d, 2H, J.9.20 Hz, H-3), 7.73 (d, 2H, J.1.80 Hz, H-8), 7.93 (d, 4H, J.9.10 Hz, H-4,5). ${ }^{13} \mathrm{C} \mathrm{NMR}\left(\mathrm{CDCl}_{3}\right)$, $\delta$, ppm: $24.5\left(\mathrm{CH}_{2}\right), 116.3(\mathrm{C}-8), 118.69\left(\mathrm{q},{ }^{1} J_{\mathrm{CF}} .320 .52 \mathrm{~Hz}, \mathrm{CF}_{3}\right), 118.72\left(\mathrm{q},{ }^{1} J_{\mathrm{CF}} 320.52 \mathrm{~Hz}\right.$, $\mathrm{CF}_{3}$ ), 120.9 (C-3), 121.3 (C-6), 127.4 (C-1), 130.5 (C-4), 131.9 (C-5), 132.0 (C-10), 132.9 (C-9), 146.4 (C-7), 148.3 (C-2). ${ }^{19} \mathrm{~F}$ NMR $\left(\mathrm{CDCl}_{3}\right), \delta$, ppm: -72.9 (s), -73.2 (s). MS (MALDI-TOF), $m / z: 1099\left[\mathrm{M}+2 \mathrm{CHCl}_{3}\right]$. For $\mathrm{C}_{25} \mathrm{H}_{12} \mathrm{~F}_{12} \mathrm{O}_{12} \mathrm{~S}_{4}$, calcd., \%: C 34.89; $\mathrm{H} 1.41$. Found, \%: C 34.77; $\mathrm{H}$ 1.08 .

2,2'-Bis(trifluoromethanesulfonyloxy)-7,7'-bis(phenylamino)-1,1-dinaphthylmethane (13). A mixture of BINAP $(0.012 \mathrm{~g}, 0.019 \mathrm{mmol})$ and $\mathrm{Pd}(\mathrm{OAc})_{2}(0.003 \mathrm{~g}, 0.013 \mathrm{mmol})$ in toluene $(10$ $\mathrm{mL}$ ) was heated for $5 \mathrm{~min}$ at $85{ }^{\circ} \mathrm{C}$ with stirring under argon, and then tetrakis(trifluoromethanesulfonyloxy)-1,1-dinaphthylmethane $12(0.14 \mathrm{~g}, 0.16 \mathrm{mmol})$, aniline $(0.18 \mathrm{~g}, 1.95 \mathrm{mmol})$, and $\mathrm{Cs}_{2} \mathrm{CO}_{3}(0.63 \mathrm{~g}, 1.95 \mathrm{mmol})$ were added, and the reaction mixture was heated for $5 \mathrm{~h}$ at $110{ }^{\circ} \mathrm{C}$. The precipitate was filtered off, the filtrate was concentrated, and the product was isolated by column chromatography (silica gel, hexane, benzene/hexane, 1/ 1) and dried at $90-100{ }^{\circ} \mathrm{C}(1 \mathrm{~mm} \mathrm{Hg})$. Dark gray powder. Yield $0.09 \mathrm{~g}(70 \%) . \mathrm{mp} 164-165{ }^{\circ} \mathrm{C} .{ }^{1} \mathrm{H}$ NMR $\left(\mathrm{CDCl}_{3}\right) \delta$, ppm: 4.76 (s, 2H, $\mathrm{CH}_{2}$ ), 5.73 (br.s, 2H, NH), 6.90 (d, 4H, J.7.8 Hz, H-oPh), 7.03 (t, 2H, J.7.4 Hz, H-pPh), 7.06 (d, 2H, J.8.7 Hz, H-3), 7.08 (dd, 2H, J.8.7, 1.8 Hz, H-6), 7.15 (d, 2H, J.1.9 Hz, H-8), 7.25 (dd, 4H, J =8.3, 7.8 Hz, H-mPh), 7.62 (d, 2H, J.8.8 Hz, H-5), 7.64 (d, 2H, J.8.7 Hz, H-4). ${ }^{13} \mathrm{C}$ NMR $\left(\mathrm{CDCl}_{3}\right), \delta$, ppm: $24.7\left(\mathrm{CH}_{2}\right), 106.4(\mathrm{C}-8), 116.4(\mathrm{C}-3), 118.5$ (q, $\left.{ }^{1} J_{\mathrm{CF} .} 322.5 \mathrm{~Hz}, \mathrm{CF}_{3}\right), 119.82(\mathrm{C}-o \mathrm{Ph}, \mathrm{C}-6), 122.7(\mathrm{C}-p \mathrm{Ph}), 125.4(\mathrm{C}-9), 127.8(\mathrm{C}-1), 129.2(\mathrm{C}-4)$, $129.6(\mathrm{C}-m \mathrm{Ph}), 130.2(\mathrm{C}-4), 134.2(\mathrm{C}-10), 141.3(\mathrm{C}-i \mathrm{Ph}), 143.1$ (C-7), $146.3(\mathrm{C}-2) .{ }^{19} \mathrm{~F}$ NMR $\left(\mathrm{CDCl}_{3}\right), \quad \delta, \quad$ ppm: $\quad-73.2 \quad(\mathrm{~s}) . \quad \mathrm{MS} \quad(\mathrm{MALDI}-\mathrm{TOF}), \quad m / z: 808 \quad\left[\mathrm{M}^{+}+\mathrm{K}^{+}+\mathrm{Na}^{+}\right]$. For $\mathrm{C}_{35} \mathrm{H}_{24} \mathrm{~F}_{6} \mathrm{~N}_{2} \mathrm{O}_{6} \mathrm{~S}_{2} \cdot \mathrm{C}_{6} \mathrm{H}_{6}$, calcd. \%: C 59.70; H 3.67; N 3.40. Found, \%: C 59.41; H 3.69; N 3.23.

2,2'-Bis(trifluoromethanesulfonyloxy)-1,1-dinaphthylmethane (14) was prepared similarly to compound 12 by the reaction of 2,2'-dihydroxy-1,1-dinaphthylmethane 2 (0.11 g, $0.3 \mathrm{mmol})$ with trifluoromethanesulfonic anhydride $(0.79 \mathrm{~g}, 2.8 \mathrm{mmol})$. Brown powder. Yield $0.16 \mathrm{~g}(78 \%)$. mp114-115 ${ }^{\circ} \mathrm{C} .{ }^{1} \mathrm{H}$ NMR $\left(\mathrm{CDCl}_{3}\right), \delta$, ppm: 5.04 (s, 2H, $\left.\mathrm{CH}_{2}\right), 7.37$ (dd, 2H, J.8.2, $\left.7.3 \mathrm{~Hz}, \mathrm{H}-6\right)$, 7.45 (dd, 2H, J.8.7, 6.0 Hz, H-7), 7.47 (d, 2H, J.9.2 Hz, H-3), 7.83 (d, 4H, J.9.1 Hz, H-4,5), 7.84 (d, 2H, J.9.1 Hz, H-8). ${ }^{13} \mathrm{C}$ NMR $\left(\mathrm{CDCl}_{3}\right), \delta$, ppm: $24.7\left(\mathrm{CH}_{2}\right), 118.7\left(\mathrm{q},{ }^{1} J_{\mathrm{CF}} .319 .2 \mathrm{~Hz}, \mathrm{CF}_{3}\right)$, 119.5 (C-3), 124.4 (C-4 or C-5), 126.9 (C-7), 127.6 (C-1), 127.7 (C-6), 129.1 (C-8), 130.0 (C-4 or C-5), 132.6 (C-10), 132.9 (C-9), $145.6(\mathrm{C}-2) .{ }^{19} \mathrm{~F} \mathrm{NMR}\left(\mathrm{CDCl}_{3}\right), \delta, \mathrm{ppm}:-73.2$ (s). For $\mathrm{C}_{23} \mathrm{H}_{14} \mathrm{~F}_{6} \mathrm{O}_{6} \mathrm{~S}_{2}$, calcd., \%: C 48.94; H 2.50. Found, \%: C 48.62; H 2.46. 
Reaction of $2,2^{\prime}, 7,7^{\prime}$-tetrakis(trifluoromethanesulfonyloxy)-1,1-dinaphthylmethane 12 with hexylamine was carried out similarly to the synthesis of compound $\mathbf{1 3}$ using BINAP (0.008 g, $0.012 \mathrm{mmol}), \mathrm{Pd}(\mathrm{OAc})_{2}(0.002 \mathrm{~g}, 0.008 \mathrm{mmol})$, tetrakis(trifluoromethanesulfonyloxy)-1,1dinaphthylmethane $12(0.09 \mathrm{~g}, 0.11 \mathrm{mmol})$, hexylamine $(0.13 \mathrm{~g}, 1.27 \mathrm{mmol})$, and $\mathrm{Cs}_{2} \mathrm{CO}_{3}(0.41$ $\mathrm{g}, 1.27 \mathrm{mmol}$ ). The products were separated by column chromatography (silica gel, hexane, hexane: dioxane.10:1), the solvent was distilled off, and the residues were dried at $100-110{ }^{\circ} \mathrm{C}(1$ $\mathrm{mm} \mathrm{Hg}$ ).

Macrocycle 15. Brown oil. Yield $0.0095 \mathrm{~g}(6.5 \%) .{ }^{1} \mathrm{H}$ NMR (acetone- $\left.\mathrm{d}_{6}\right) \delta$, ppm: $0.88(\mathrm{t}, 6 \mathrm{H}$, J.6.9 Hz, $\left.\mathrm{CH}_{3}\right), 1.26-1.58\left(\mathrm{~m}, 16 \mathrm{H}, \mathrm{CH}_{2}\left(\underline{\mathrm{CH}}_{2}\right)_{4} \mathrm{CH}_{3}\right), 2.84$ (t, $\left.4 \mathrm{H}, J .6 .9 \mathrm{~Hz}, \underline{\mathrm{CH}_{2}}\left(\mathrm{CH}_{2}\right)_{4} \mathrm{CH}_{3}\right), 4.84$ (s, 4H, $\mathrm{CH}_{2}$ ), 6.69 (d, 4H, J.1.9 Hz, H-8), 6.94 (dd, 4H, J.8.7, 2.7 Hz, H-6), 7.16 (d, 4H, J.9.2 $\mathrm{Hz}, \mathrm{H}-3), 7.59$ (d, 4H, J.8.7 Hz, H-5), 7.74 (d, 4H, J.8.7 Hz, H-4). ${ }^{13} \mathrm{C}$ NMR (acetone-d 6 ), $\delta$, ppm: $13.5\left(\mathrm{CH}_{3}\right), 22.5\left(\mathrm{CH}_{2}\right), 24.6\left(\mathrm{CH}_{2}\right), 26.8\left(\mathrm{CH}_{2}\right), 31.5\left(\mathrm{CH}_{2}\right), 43.1\left(\mathrm{CH}_{2}\right), 99.2(\mathrm{C}-8), 113.7$ (C-3), 119.3 (q, ${ }^{1} J_{\mathrm{CF} .} 320.7 \mathrm{~Hz}, \mathrm{CF}_{3}$ ), 119.4 (C-6), 124.7 (C (quaternary)), 126.2 (C (quaternary)), 129.5 (C-5), 129.7 (C-4), 135.1 (C (quaternary)), 146.5 (C-2), 148.2 (C-7). ${ }^{19} \mathrm{~F} \mathrm{NMR}\left(\mathrm{CDCl}_{3}\right), \delta$, ppm: -73.3 (s). MS (MALDI-TOF), m/z: $1175\left[\mathrm{M}^{+}\right.$-OTf]. For $\mathrm{C}_{58} \mathrm{H}_{50} \mathrm{~F}_{12} \mathrm{O}_{12} \mathrm{~S}_{4} \mathrm{~N}_{2}$, calcd. \%: C 52.64; H 3.81; N 2.12. Found, \%: C 52.86; H 4.00; N 2.16.

Macrocycle 16. Brown oil. Yield $0.015 \mathrm{~g}(10 \%) .{ }^{1} \mathrm{H}$ NMR (acetone- $\left.\mathrm{d}_{6}\right) \delta$, ppm: 0.87 (t, 6H, J.6.7 $\left.\mathrm{Hz}, \mathrm{CH}_{3}\right), 1.25-1.52\left(\mathrm{~m}, 16 \mathrm{H}, \mathrm{CH}_{2}\left(\underline{\mathrm{CH}}_{2}{ }_{4} \mathrm{CH}_{3}\right), 2.77\right.$ (t, $4 \mathrm{H}$, J.7.1 Hz, $\left.\underline{\mathrm{CH}}_{2}\left(\mathrm{CH}_{2}\right)_{4} \mathrm{CH}_{3}\right), 5.02$ (s, $4 \mathrm{H}, \mathrm{CH}_{2}$ ), 6.53 (d, 1H, J.1.8 Hz, H-8'), 6.97 (dd, 1H, J.8.7, $1.8 \mathrm{~Hz}, \mathrm{H}-6$ '), 7.19 (d, 1H, J.9.2 Hz, H-3), 7.62 (d, 1H, J.8.7 Hz, H-5'), 7.64 (dd, 1H, J.9.2, 2.2 Hz, H-6), 7.77 (d, 1H, J.8.7 Hz, H-3'), 7.78 (d, 1H, J.8.7 Hz, H-4), 8.08 (d, 1H, J.2.3 Hz, H-8), 8.23 (d, 1H, J.7.4 Hz, H-4'), 8.26 (d, 1H, J.8.4 Hz, H-5). ${ }^{13} \mathrm{C}$ NMR (acetone-d $\left.{ }_{6}\right), \delta$, ppm: $13.5\left(\mathrm{CH}_{3}\right), 22.5\left(\mathrm{CH}_{2}\right), 24.6\left(\mathrm{CH}_{2}\right), 26.8\left(\mathrm{CH}_{2}\right)$, $31.6\left(\mathrm{CH}_{2}\right), 43.0\left(\mathrm{CH}_{2}\right), 98.7\left(\mathrm{C}-8{ }^{\prime}\right), 113.9(\mathrm{C}-3), 116.7(\mathrm{C}-8), 118.72\left(\mathrm{q},{ }^{1} J_{\mathrm{CF}} .320 .1 \mathrm{~Hz}, \mathrm{CF}_{3}\right)$, 118.77 (q, ${ }^{1} J_{\mathrm{CF}} .320 .2 \mathrm{~Hz}, \mathrm{CF}_{3}$ ), $119.5\left(\mathrm{C}-6^{\prime}\right), 121.1$ (C-6), 121.2 (C-3'), 123.4 (C (quaternary)), 126.4 (C (quaternary)), 128.8 (C (quaternary)), 129.9 (C (tertiary)), 130.1 (C (tertiary)), 130.5 (C (tertiary)), 132.38 (C (quaternary)), 132.44 (C-5), 133.1 (C (quaternary) ), 134.6 (C (quaternary)), 146.3 (C-2), $146.9\left(\mathrm{C}-2^{\prime}\right), 148.2$ (C-7'), $148.4(\mathrm{C}-7) .{ }^{19} \mathrm{~F}$ NMR $\left(\mathrm{CDCl}_{3}\right)$, $\delta$, ppm: -

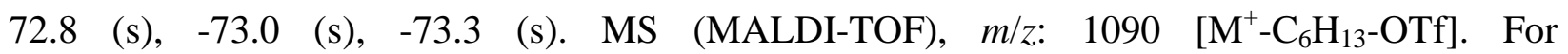
$\mathrm{C}_{58} \mathrm{H}_{50} \mathrm{~F}_{12} \mathrm{~N}_{2} \mathrm{O}_{12} \mathrm{~S}_{4}$, calcd. \%: C 52.64; H 3.81; N 2.12. Found, \%: C 52.43; H 3.71; N 2.24.

\section{Acknowledgements}

The work was supported in part by the Russian Foundation for Basic Research (project no. 0903-00201a). 


\section{References}

1. (a) Zaoying, L.; Jianglin, L.; Cong, L.; Wei, X.. Synth. Commun. 2000. 30. 917. (b) Vyskocil, S.; Smrcina, M.; Lorenc, M.; Tislerova, I.; Brooks, R. D.; Kulagowski, J. J.; Langer, V.; Farrugia, L. J.; Kocovsky, P. J. Org. Chem. 2001, 66, 1359. (c) Che, Ch.-M.; Kwong, H.-L.; Chu, W.-Ch.; Cheng, K.-F.; Lee, W.-S.; Yu, H.-S.; Yeung, Ch.-T.; Cheung, K.-K.. Eur. J. Inorg. Chem. 2002, 6, 1456. (d) Burchell, T. J.; Eisler, D. J.; Puddephatt, R. J. Dalton Trans. 2005, 2, 268. (e) Ma, G.-N.; Zhang, Y.-P.; Shi, M.. Synthesis. 2007, 197. (f) Herrmann, W. A.; Baskakov, D.; Ruhland, K. J. Heterocycl. Chem. 2007, 44, 237. (g) Ryoo, J. J.; Armstrong, D. W. Bull. Korean Chem. Soc. 2007, 28, 2103. (h) Zi, G.; Liu, X.; Xiang, L.; Song, H. Organometallics. 2009, 28, 1127. (i) Xiang, L.; Zhang, F.; Zhang, J.; Song, H.; Zi, G.; Inorg. Chem. Commun. 2010, 13, 666. (j) Zi, G.; Zhang, F.; Liu, X.; Ai, L.; Song, H. J. Organometallic Chem. 2010, 695, 730.

2. (a) Maslennikova, V. I.; Sotova, T. Yu.; Vasyanina, L. K.; Bauer, I.; Habicher, W. D.; Nifantyev, E. E. Tetrahedron Lett. 2005, 46, 4891. (b) Maslennikova, V. I.; Sotova, T. Yu.; Vasyanina, L. K.; Lyssenko, K. A.; Antipin, M. Yu.; Adamson, S. O.; Dementyev, A. I.; Habicher, W. D.; Nifantyev, E. E. Tetrahedron 2007, 63, 4162.

3. DAHL and COMP in BARMEN. Patent D. E. 75755. 1893.

4. Nifantyev E. E.; Maslennikova V. I.; Shelenkova L. V.; Levina I. I.; Polekhin D. M. Mendeleev Commun. 2009, 101.

5. (a) Bucherer, H. Th. J.Prakt.Chem. 1904, 69, 49. (b) Bucherer, H. Th.; Seyde, F. J.Prakt.Chem. 1907, 75, 249. (c) Bucherer, H. Th. J.Prakt.Chem.. 1904, 70, 345. (d) Bucherer, H. Th.; Stohmann, A. J.Prakt.Chem. 1905, 71, 433. (e) Huismann J.; Duisberg W.; Hentrich W.; Zeh L. U.S. Patent 1543569. 1925 (f) Louie, J.; Driver, M. S.; Hamann, B. C.; Hartwig, J.F. J. Org. Chem. 1997, 62, 1268. (g) Wolfe, J. P.; Buchwald, S. L. J. Org. Chem. 1997, 62, 1264. (h) Wolfe, J. P.; Ahman, J.; Sadighi, J. P.; Singer, R. A.; Buchwald, S. L. Tetrahedron Lett. 1997, 38, 6367. (i) Canete, A.; Melendrez, M. X.; Saitz, C.; Zanocco, A. L. Synth. Commun. 2001, 31, 2143

6. (a) Bogdanov, S. V. Zh. Obshch. Khim. 1932, 2, 770. (b) Bogdanov, S. V.; Karandashova, N. N. Zh. Obshch. Khim. 1956, 26, 3365. (c) Rieche, A.; Seeboth, H. Justus Liebigs Annalen der Chemie. 1960, 638, 66. (d) Seeboth H. Angew. Chem. Int. Ed. 1967, 6, 307.

7. (a) Wolff, W. Chem. Ber. 1893, 26, 85. (b) Kallmayer, H.-J.; Schroeder-Mann, St. Sci. Pharm. 1998, 66, 1.

8. Louie, J.; Driver, M. S.; Hamann, B. C.; Hartwig, J. F. J. Org. Chem. 1997, 62, 1268. 